\title{
'Necton' sulla - A preliminary agronomic evaluation
}

\author{
HARI KRISHNA, PETER D. KEMP and the late SALLY D. NEWTON \\ Agronomy Department, Massey University, Palmerston North
}

\begin{abstract}
'Necton' sulla (Hedysarum coronarium L.) is a perennial forage legume with potential to provide high quality, non-bloating feed. This trial examined the effect of grazing intensity and frequency on sulla over one year. Annual dry matter yields ranged from 7.4 to $18.0 \mathrm{t} / \mathrm{ha}$. There was no difference in the yield of hardand lax-grazed plots but grazing in late autumn significantly decreased plant density and yield.
\end{abstract}

Keywords 'Necton', sulla, legume, grazing management

\section{Introduction}

Sulla (Hedysarum coronarium L.) is a herbaceous, short-lived perennial legume that grows $80-175 \mathrm{~cm}$ high and has a strong deep tap-root and numerous secondary roots. It is used in Mediterranean countries such as southern Italy, Spain, Tunisia, Turkey and in some parts of Australia for hay and silage making, and soil conservation. Sulla was introduced into New Zealand in the early 1950s largely for use in soil conservation, but its pōtentiäl as a forage was more fully realised in 1982 (Watson 1982). There are two cultivars available in New Zealand, 'Necton' and 'Aokau'. Sulla produces high quality herbage which is readily eaten by stock. The condensed tannin content of sulla is approximately 4-5\% DM (Tom Terrill pers. comm.), which eliminates the risk of bloat. Moreover, weight gains in lambs fed sulla were greater than those in lambs fed sulla with tannin effects removed (Barry 1989; Deadman 1989).

Recent cutting trials by MAF in Hawke's Bay and by NZ Agriseeds Limited in Canterbury produced annual DM yields from sulla of 12-18 tha (Rys et $\boldsymbol{a l}$. 1988; Graham Kerr pers. comm.). Similar yields were obtained in cutting trials in the Manawatu (Douglas 1984; Douglas \& Foote 1985).

Although sulla has shown promise as a high quality forage, knowledge of its performance under grazing is scarce. There is a need to develop grazing management guidelines for sulla and to improve its establishment and persistence (Foote 1988; Rys \& al. 1988). The objective of this trial was to examine the effect of grazing intensity and frequency on the production of sulla over one year. The trial also provided experience with the establishment of sulla.

\section{Materials and methods}

The trial was started on 27 September 1988 on 0.22 ha of a Tokomaru silt loam at Massey University. The soil was ploughed in early spring 1988 and agricultural lime at $4 \mathrm{t} / \mathrm{ha}$ was incorporated to increase the $\mathrm{pH}$ from 5.5 to 6.0 . $30 \%$ potassic super at $450 \mathrm{~kg} / \mathrm{ha}$ was applied at sowing. Dehulled 'Necton' sulla seed, supplied by Agriseeds Limited, was inoculated with rhizobia strain NZPA 5410 and drilled at $7.0 \mathrm{~kg} / \mathrm{ha}$. Apparent nodulation failure resulted in pronounced yellowing of herbage and urea was broadcast at the rate of $100 \mathrm{~kg} \mathrm{~N} / \mathrm{ha}$ on 17 October 1988 and after each grazing. Plant tissue analysis was used to monitor the remedial measures taken. Plots were hand weeded.

A randomised complete block design with split plots and 6 treatments with 3 replicates was used. Plot size was $120 \mathrm{~m}^{2}$. The grazing treatments began when the plants were at the early reproductive (ER) growth stage 85 days after sowing (DAS). The main $\overline{\text { plōts }}$ were $(1)^{-}$hard $^{-}$grazed $^{-}$(approximately $-75 \%$ of leaf and stem material eaten leaving residual of $500-700 \mathrm{~kg} \mathrm{DM} / \mathrm{ha}$, (2) lax grazed (approximately $60 \%$ of the leaf and stem material eaten leaving residual of $1000-1200 \mathrm{~kg} \mathrm{DM} / \mathrm{ha}$ ), or (3) zero grazed (no herbage removed). At $105 \mathrm{DAS}$, and at subsequent grazings, the zero grazedmain plots were split and the subplots grazed either hard or lax. The plants in this treatment were at the late reproductive (LR) growth stage when first grazed. The hard and lax grazed main plots were split and subplots grazed either hard or lax at 140 DAS and at subsequent grazings. The hard and lax grazed main plots were grazed whenever the plants were at the ER growth stage and the zero grazed main plot when the plants were at the LR growth stage; thus, the plots were grazed 4 and 3 times in a year respectively. The ER growth stage was defined as mid to late stem elongation and the LR growth stage as $10 \%$ of stems flow ering.

All grazings were by mature ewes. Three $0.4 \mathrm{~m}^{2}$ quadrats were used to measure available/residual $\mathrm{DM}$ and plant density in each plot. 
Table 1 Cumulative DM yield (kg/ha) of 'Necton' sulla grazed at different growth stages and intensities over 365 days. (Number of grazings shown in brackets).

\begin{tabular}{|c|c|c|c|c|}
\hline \multirow[t]{2}{*}{ Growth } & \multicolumn{4}{|c|}{ Grazing intensity } \\
\hline & Hard & $\begin{array}{c}\text { Hard/ } \\
\text { Lax }\end{array}$ & $\begin{array}{l}\text { Lax/ } \\
\text { Hard }\end{array}$ & Lax \\
\hline $\begin{array}{l}\text { ER (4) } \\
\text { LR (3) } \\
\end{array}$ & $\begin{array}{c}7627 \\
17943^{*} \\
\end{array}$ & $\begin{array}{r}8923 \\
- \\
\end{array}$ & $\begin{array}{c}7371 \\
-\end{array}$ & $\begin{array}{r}9887 \\
18003^{*} \\
\end{array}$ \\
\hline
\end{tabular}

* Pair of means within column significantly different $(\mathrm{P}<0.05)$

- Not applicable

\section{Results}

The annual herbage yield over 365 DAS of 'Necton' sulla grazed 3 times at LR growth stage was approximately twice that of sulla grazed 4 times at ER growth stage (Table 1). The intensity of grazing did not affect the annual yield of sulla, but the net utilisation of pregrazed yield was $72 \%$ over all hard grazed treatments, and $62 \%$ over all lax grazed treatments. There was no interaction effect between grazing intensity and grazing frequency on annual DM yield (Table 1). The initial grazing intensities of hard, lax, or zero resulted in no significant difference in the annual DM yield of the hard and lax grazed main plots.

Plant density, shoot yield per plant, and daily growth rate per ha were similar for the ER and LR growth stage treatments up to the grazings in autumn (Table 2). The final autumn grazing of the ER growth stage treatment occurred on 18 March, whereas that for the LR growth stage treatment was on 29 May. At the following spring harvest (28 September) the plant density of the ER growth stage treatment was $28 \%$ of that of the LR growth stage treatment (Table 2). Similarly, the daily growth rate over winter of the ER growth stage treatment was $22 \%$ of that of the LR growth stage treatment, suggesting that either lateness of autumn grazing or growth stage at grazing affected plant density and thereby daily growth rate (Table 2). Plant density, shoot yield per plant, and daily growth rate were unaffected by grazing intensity with the exception of an interactive effect of grazing intensity and growth stage on shoot yield per plant at 28 September harvest (Table 3).

The shoot yield per plant was lower for plants grazed hard rather than lax in autumn at the ER growth stage, but not for plants grazed at the LR growth stage (Table 3). Over the 365 day, shoot yield per plant increased and plant density decreased in all treatments (Tables 2 and 3).

\section{Discussion}

The annual DM yield of 'Necton' sulla ranged across the treatments from 7.4 to $18.0 \mathrm{t} / \mathrm{ha}$, which was similar to the $12-18 \mathrm{t} /$ ha reported under cutting and grazing trials (Table 1, Douglas 1984; Rys et al. 1988). Sulla grew throughout the year with high growth rates in summer and low growth rates in winter (see Table 2).

DM yield was unaffected by the intensity of grazing, but was affected by either the growth stage at grazing, or more probably, nearness to winter of autumn grazing (Tables 1 and 2). The experimental design did not allow for the possible effect of late autumn grazing on subsequent yield but this will need to be examined. Nevertheless, the large decrease in plant density and the consequent decrease in growth rate and yield in the ER growth stage treatment grazed in late May suggests that grazing sulla in late autumn needs to be avoided (see Table 2).

Table 3 Shoot DM yield per plant (g) of 'Necton' sulla at different growth stages and grazing intensities on 28 September 1989, 365 DAS.

\begin{tabular}{|c|c|c|c|c|}
\hline \multirow[t]{2}{*}{ Growth } & \multicolumn{4}{|c|}{ Grazing intensity } \\
\hline & Hard & $\begin{array}{c}\text { Hard/ } \\
\text { Lax }\end{array}$ & $\begin{array}{l}\text { Lax/ } \\
\text { Hard }\end{array}$ & Lax \\
\hline $\begin{array}{l}\text { ER (4) } \\
\text { LR (3) }\end{array}$ & $\begin{array}{l}11.7 \\
\mathbf{2 0 . 3}\end{array}$ & $\begin{array}{r}30.1 \\
-\end{array}$ & $\begin{array}{l}12.6 \\
-\end{array}$ & $\begin{array}{l}28.6 \\
30.1\end{array}$ \\
\hline
\end{tabular}

LSD $5 \%=12.0$

Table 2 Effect of growth stage at grazing on plant density (plants $/ \mathrm{m}^{2}$ ), shoot DM yield per plant $(\mathrm{g})$ and net daily growth rate (kg DM/ha) of 'Necton' sulla over 365 days. Values meaned over all grazing intensities.

\begin{tabular}{|c|c|c|c|c|c|c|}
\hline \multirow[t]{2}{*}{ Growth stage } & \multicolumn{6}{|c|}{ Date of grazing } \\
\hline & $\begin{array}{c}22 / 12 / 88 \\
85\end{array}$ & $\begin{array}{c}11 / 1 \\
105\end{array}$ & $\begin{array}{c}16 / 2 \\
140\end{array}$ & $\begin{array}{c}18 / 3 \\
172\end{array}$ & $\begin{array}{c}29 / 5 \\
240\end{array}$ & $\begin{array}{c}28 / 9 / 89 \\
365 \text { DAS* }\end{array}$ \\
\hline & \multicolumn{6}{|c|}{ density } \\
\hline ER (4) & $85 \pm 7.0$ & - & $64 \pm 6.7$ & - & $45 \pm 2.8$ & $14 \pm 1.4$ \\
\hline $\operatorname{LR}(3)$ & $=$ & $92 \pm 8.9$ & - & $60 \pm 7.2$ & - & $50 \pm 2.5$ \\
\hline $\begin{array}{l}\operatorname{ER}(4) \\
\operatorname{LR}(3)\end{array}$ & $\begin{array}{c}3.2 \pm 0.9 \\
-\end{array}$ & $3.9 \pm 1.0$ & $\begin{array}{c}5.4 \pm 1.0 \\
-\end{array}$ & $6.3 \pm 2.6$ & $\begin{array}{c}9.8 \pm 3.4 \\
-\end{array}$ & $\begin{array}{l}20.7 \pm 1.8 \\
25.1 \pm 2.6\end{array}$ \\
\hline $\begin{array}{l}\operatorname{ER~(4)~} \\
\operatorname{LR}(3)\end{array}$ & $\begin{array}{c}28 \pm 2.5 \\
-\end{array}$ & $34 \pm 6.0$ & $42 \pm 7.8$ & $\begin{array}{l}\text { rate } \\
\qquad 46 \pm 1.3\end{array}$ & $\begin{array}{c}22 \pm 2.1 \\
-\end{array}$ & $\begin{array}{l}13 \pm 2.1 \\
59 \pm 6.8\end{array}$ \\
\hline
\end{tabular}

*Days after sowing 
Sulla behaved similarly to other perennial forage legumes such as lucerne and red clover in that plant density declined over time and plant size (shoot yield per plant) increased (Table 2 and 3; Leach 1967; Hay \& Ryan 1989). The factor that had the greatest effect on plant density was late autumn grazing, whereas the interaction between hard grazing and late autumn grazing had the greatest effect on plant size (Tables 2 and 3). Lax grazing in late autumn did not affect plant size (Table 3). The low plant density in the ER growth stage treatment on 28 September was not compensated for by an increase in plant size relative to plants in the other treatments, suggesting that the maximum plant size for the conditions had been attained. Therefore, grazing in late autumn, and particularly hard grazing, decreased total yield by decreasing plant density below the point that could be compensated for by an increase in plant size. Presumably, plants die during winter from treading damage to growing points, lack of stored carbohydrate, insufficient active leaf area, or disease. These factors will be examined in future trials.

Although sulla was grown with the use of urea due to nodulation failure in this trial, the growth and production of effectively nodulated sulla in current trials appears similar to that of sulla grown with urea. An effective rhizobia strain ICMP 10149 was selected as part of the current sulla programme and is now commercially available.

\section{Conclusions}

Sulla has the potential to provide high yields of nonbloating forage over spring, summer and autumn provided it is grazed when between the early stem elongation and $10 \%$ flowering-growth-stages-Hardgrazing the plants so that all leaflets were removed did not affect regrowth but grazing in late autumn or winter killed plants and decreased yield. The death of sulla plants grazed in winter has been identified as a management problem that requires further research, particularly as sulla is winter active.

\section{ACKNOWLEDGEMENTS}

The authors thank NZ Agriseeds Ltd for their financial support, G. Kerr, G.B. Douglas and AS. Foote for their advice, and T.J. Lynch and R.J. Battersby for their technical assistance.

\section{REFERENCES}

Barry, T.N. 1989. Condensed tannins: their role in ruminant protein and carbohydrate digestion and possible effects upon the rumen ecosystem. pp. 153-169. In The role of protozoa and fungi in ruminant digestion. Eds J.V. Nolan, R.A. Leng \& D.I. Demeyer. Proceedings of an international seminar sponsored by the OECD Co-operative Research Project on Food Production and Preservation, and the University of New England, held 26-29 September, 1988. University of New England Press; Armidale, Australia.

Deadman, C. 1989. Nutritive value of sulla. BAgSci Honours unpublished thesis. Massey University.

Douglas, G.B. 1984. Seed production of sulla - A plant for soil conservation. Proceedings of the $N Z$ Grassland Association 45: 239-242.

Douglas, G.B.; Foote, A.G. 1985. Dry matter and seed yields of sulla (Hedysarum coronarium L.). NZ journal of experimental agriculture 13: 97-99.

Foote, A.S. 1988. Local cultivar adaptation for Mediterranean's sulla. NZ journal of agriculture Feb/Mar: 25-27.

Hay, R.J.M.; Ryan, D.L. 1989. A review of 10 years' research with red clovers under grazing in Southland. Proceedings NZ Grassland Association 50: 181-188.

Leach, G.J. 1967. Growth and development of lucerne. pp. 15-21. In The Lucerne Crop. Ed R.H.M. Langer. Wellington: Reed.

Rys, G.J.; Smith, N.; Slay, M.W. 1988. Alternative forage species in Hawkes Bay. Proceedings of the Agronomy Society of NZ 18: 75-80.

Watson, N.J. 1982. Hedysarum coronarium L. a legume with potential for soil conservation and forage. NZ agricultural science 16: 189-193. 